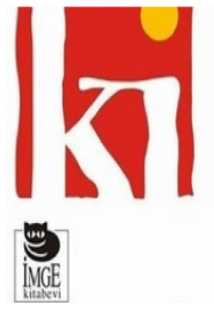

Kültür ve Iletişim

culture\&communication

Yıl: 24 Sayı: 47 (Year: 24 Issue: 47)

Mart-2021-Eylül 2021 (March 2021-September 2021)

E-ISSN: 2149-9098

2021, 24(1): 36-65

DOI: $10.18691 /$ kulturveiletisim.770227

**Araştırma Makalesi ${ }^{* *}$

\title{
Görsellik ve Hakikat: Türkiye'deki Suriyelilere Dair Sosyal Medya Görsel Paylaşımlarında Hakikat Üretim Pratikleri*
}

\author{
Balca Arda**
}

Öz

Sosyal medyada paylaşılan görseller, bugün katılımcı pratiklerin hakikat üretimindeki etkisinin artmasıyla kamuoyu oluşturmakta önemli bir yere sahiptir. Bilgi kaynaklarının geleneksel kitlesel medya kurumlarının tekelinden çıkarak sade vatandaşın çevrimiçi haber oluşturma ve bilgi yayma imkânı elde etmesi, görselin dikkat çekme ve gündem oluşturma amacıyla kullanımını daha da belirginleştirmiştir. Bu makale, Türkiye'deki Suriyeli algısını çevrimiçi kamusal alanda görsel kullanım pratikleri üzerinden incelemektedir. Bu araştırmanın amacı; sosyal medyadaki görüntü tabanlı haberler, görsel-işitsel mesajlar, söylem destekleyici veya oluşturucu argümanlar olan klipler, çok fazla paylaşılan ve hızlı yayılan imaj veya videolarda Suriyelilerin nasıl temsil edildiğini analiz etmektir. Bunun için, Suriyeliler hakkında paylaşılan görseller incelenmiştir. Türkiye'deki Suriyeli imgesinin Twitter sosyal medya platformunda paylaşımını incelemek için \#ülkemdesuriyeliistemiyorum ve \#suriyelilerkardeşimizdir hashtag'leri (\#) altındaki görseller nitel yaklaşımla kategorize edilmiştir. Araştırma sonucunda ortaya çıkarılan veri setleri çok düzlemli söylem çözümlemesi yapılarak analiz edilmiştir. Makale, hakikat üretiminde çevrimiçi katılımcıların yatay bilgi yayma pratiklerini sorgulayarak günümüzdeki bilgi kirliği sorunsalı tartışmasına görsel iletişim yönünden katkı sunmayı amaçlamaktadır. Sosyal medya platformlarında meydana gelen Türkiye'deki Suriyelilere ilişkin tartışmalarda, görüntüleri paylaşan kullanıcıların objektiflik ve tarafsızlık kaygısı taşıdıkları anlaşılmaktadır. Bu analiz, Suriyelilerin Türkiye'deki koruma statüsünün meşruiyetinin çeşitli parametrelere bağlı olduğunun ve Suriyelilere ilişkin söylemin sosyal medyada görsel kanıtlara başvurularak üretildiğini göstermiştir.

Anahtar sözcükler: Sosyal medya, Suriyeli, göç, görsel iletişim, hakikat üretimi, Türkiye.

* Geliş tarihi: 30/07/2020 • Kabul tarihi: 16/12/2020

** Kadir Has Üniversitesi İletişim Fakültesi, Görsel İletişim Tasarımı Bölümü.

Orcid no: 0000-0002-3793-2472, balca.arda@khas.edu.tr 


\title{
Visuality and the Truth: Practices of Knowledge Production through the Visuals of Syrians in Turkey on the Social Media*
}

\author{
Balca Arda**
}

\begin{abstract}
The images become the vehicle for online mass participation of ordinary users to influence media and set the agenda on specific topics among the public. The monopoly of traditional mass media institutions of information sources has been shattered through the horizontal social media practices of knowledge production and dissemination. In this age of truth skepticism, the article examines visual communication methods that activate knowledge production by taking a case study of the host communities' social media interaction on the Syrian immigrant population living under temporary protection in Turkey. The goal of this article is to identify the role of the information mediators such as clips, memes, GIFs, and videos as image-based news, audiovisual message, to construct arguments in social media. To study contrasting approaches to Syrian refugees in Turkey, I further collect images shared under two antagonistic online groupings under the hashtags \#ülkemdesuriyeliistemiyorum (I don't want Syrians in my country) and \#suriyelilerkardeşimizdir (Syrians are our siblings). I conducted the multimodal discourse analysis on this visual inventory. By this, this research-based article contributes to the studies on online participatory practices of knowledge production through visual communication. As such users who share images of Syrians in Turkey have concerns about the objectivity and impartiality of their claims. This analysis demonstrates that the legitimacy of Syrians' status in Turkey depends on various parameters that users in social media refer to through the display of visual evidence.
\end{abstract}

Keywords: Social media, Syrians, migration, visual communication, knowledge production, Turkey.

* Received: 30/072020 - Accepted: 16/12/2020

** Kadir Has University Faculty of Communication, Visual Communication Design Department Orcid no: 0000-0002-3793-2472, balca.arda@khas.edu.tr 


\section{Görsellik ve Hakikat: Türkiye'deki Suriyelilere Dair Sosyal Medya Görsel Paylaşımlarında Hakikat Üretim Pratikleri}

\section{Giriş}

Günümüzde etkisini artıran içe kapanma siyasetinin ötekisi mültecilerdir. Türkiye'de geçici koruma statüsündeki kayıtlı Suriyeli sayısı 3,7 milyona dayanmıştır (UN Refugee Agency, 2020), bu da Türkiye nüfusunun yüzde 4,5'ine denk gelmektedir. Bu veriler resmî rakamları yansıtmakta olup kayıt altında olmayan Suriyeliler ile beraber bu sayının çok daha yüksek olduğu tahmin edilmektedir. Çoğu mülteci, “Türkiye’nin transit (geçiş) durağı olması nedeniyle sosyal statüsü bulunmayan kişiler olarak Türkiye'nin toplum sistemine yabancılaşmakta ve 'öteki' olarak adlandırılmaktadır” (Özdemir ve Öner-Özkan, 2016: 229).

18 Mart 2016 tarihli Türkiye-Avrupa Birliği (AB) zirvesinde düzensiz göçü önlemeye yönelik anlaşmaya varılmasının ardından, AB'nin yükümlülükleri ve Suriyeli sığınmacıların Türkiye'deki statüsü konusundaki tartışmalar hız kazanmış ve bu mesele sosyal medyada gündem haline gelmiştir. Türkiye'nin demografik yapısı Suriye'den gelen göçle birlikte çarpıcı bir şekilde değişmiş, toplumsal entegrasyon ve adaptasyon sürecinde sorunlar baş göstermeye başlamıştır. Suriyeliler hakkındaki bilgisizlik ve özellikle yardım programları hakkındaki bilgi kirliliği Türkiye'de sürekli büyüyen Suriyeli karşıtı söylemi beslemektedir. Bu nedenle Türkiye'de entegrasyon çalışmaları kapsamında sivil toplum kuruluşlarınca Suriyeliler hakkında bilgiler paylaşılmaktadır. Ancak hem çevrimiçi hem de çevrimdışı ortamda ilgili kuruluşların sunduğu bilgilere karşıt olan ve Suriyeli karşıtı bir söylem kurulmasına neden olan bilgiler dolaşıma sokulmaktadır. Çevrimiçi katılımcılar tarafından üretilen ve paylaşılan multimedya mesajlarında Türkiye'deki Suriyelilerin statüleri konusunda tartışmalar ön plandadır.

Göç alan toplumun sosyal, politik ve ekonomik refahının sağlanmasında bu toplumdaki taraf ve bireylerin temsili ve iletişimi, dolayısıyla bu temsil ve iletişimde kullanılan görseller büyük öneme sahiptir. Çevrimiçi katılımcıların akıllı telefonlarında 
oluşturdukları mesajlar; çeşitli kitlesel medya otoriteleri tarafından tasdik edilmeden, doğrudan dolaşıma girmektedir. Böylelikle, "uzmanlık gerektiren bilgi yerine bir görüş havuzu sunan Twitter" (Lewandowsky vd., 2017: 354), kamuoyunun gündemini belirleyebilmektedir. Post-hakikat çağı olarak adlandırılan günümüzde amatör ve profesyonel bilgi üreticisi arasındaki ayrımın belirsizleşmesi, profesyonellerin ideolojik olarak daha büyük bir yapıya bağlı kişiler oldukları ve taraflı bilgi ürettikleri görüşüyle de ivme kazanmıştır.

Görsel içerik, post-hakikat çağında sosyal medyanın en önemli bileşenlerinden biridir. Bu makalede; bilgi kirliliği ve kutuplaşması olarak tanımlanan, yatay haber almaverme sistemiyle bağdaştırılan post-hakikat çağında, Suriyelilere dair görsellerin ne tür bir söylem oluşturduğu araştırılmaktadır. Görsel paylaşımlar; popüler kültür ve sanatsal referanslar aracılığıyla grafik, illüstrasyon, video ve film gibi başka öğeleri de içermektedir. İletişim sistemlerinin ve karşılıklı katılım kültürünün birbirine bağımlılığının artmasına paralel olarak; eski ve yeni medyaların yakınsaması, çağdaş görsel kültür koşulunun bir parçasıdır (Jenkins, 2006: 12). Dolayısıyla, çevrimiçi bilgi üretiminde kullanılan görseller, yakınsama kültürünün bir örneği olarak multimedya ürünüdür. "Görseller ikna edici ve duyguları harekete geçiren (affective) ürünler" (Lackovic, 2020: 443) oldukları için, kullanıcıların içerik üretirken başvurdukları temel araç haline gelmiştir. Görsel temelli multimedya paylaşımlar, özellikle sosyal ve doğal krizler, "ihtilaflı medya olayları" (Mortensen, 2015) olarak da bilinen felaketler veya savaş gibi durumlarda daha da önem kazanır. Tanıdığımız ve hatırladığımız olaylar, öncelikle görüntüler yoluyla aktarıldığından, görüntülerin önemi sosyal medyada duyguları harekete geçiren zamanlarda belirginleşmektedir (Bruns ve Hanusch, 2017: 1124). Görsellik, katılımcı medyanın özellikle ihtilaflı medya olaylarında tanıklık eylemini gerçekleştirmesinde rol oynamaktadır (Scott, 2019: 374).

Görselliğin özellikle intilaflı durumlarda bu kadar önemli olduğu bir çağda, Türkiye'deki Suriyelilere dair görsel paylaşımlar yoluyla oluşturulan söylem, önem kazanmaktadır. Bu doğrultuda, çalışmada Suriyeliler hakkındaki görsellerin dayanışma 
ve ötekileştirme mekanizması olarak nasıl kullanıldığını sorgulamaktadır. Görsellerin niteliklerinin nasıl bir formasyon izlediği ve bu görsel formasyonun post-hakikat çağı olarak adlandırılan günümüzde hakikat üretimindeki rolü incelenecektir. Twitter'da Türkiye'deki Suriyelilerle ilgili paylaşım yapılırken görsellerin ne şekillerde kullanıldığı incelenirken görsellerin estetik, üslup ve kompozisyonları temel alınmıştır. Burada, görsellerin estetik öğeleri çok düzlemli söylem analizi aracılığıyla analiz edilecektir. Söylem analizinin amacı; paylaşılan görsellerin, Suriyeliler hakkındaki destekleyici ve eleştirel, kültürel, ekonomik, siyasî, idarî ana argümanlar ile ilişkilendirilmesidir. Araştırma soruları şunlardır:

- Suriyeli karşıtı veya Suriyeli yanlısı sosyal medya paylaşımlarındaki görüntüler; konu, biçim ve içerik açısından hangi yönlerden farklıdır?

- Suriyeliler bu görüntülerde -olumlu ya da olumsuz olarak- nasıl temsil edilmektedir?

- Paylaşılan bu görüntülerin genel estetik özellikleri nelerdir? Paylaşılan bu görüntülerde hangi popüler kültür öğelerini ve referanslarını tespit edebiliriz?

Söylem analizi, bir popülasyondan istatistiksel olarak temsilî bir örnek elde etmek yerine popülasyondan yeterli kanıt toplamayı amaçlar. Söylem analizi, görüntüler ve beraberindeki metinlerin izleyiciler için nasıl belirli bir gerçeklik versiyonu oluşturduğunu araştırır (Kenney, 2010). Görüntüler her zaman diğer ilgili görseller ve ilgili yazılı metinlerle birlikte bir anlam zinciri kurar (Aiello \& Thurlow, 2006). Dolayısıyla izleyicinin görüntüden anlamı belirleyen, yalnızca görüntünün ne gösterdiği değil; aynı zamanda bağlamsal olarak ilişkide bulunduğu tarihsel, sosyo-politik ve kültürel koşullardır. Gunther Kress ve Theo van Leeuwen'in (2001: 26) ifade ettiği gibi, "dil bağlamında çalışan göstergebilimsel çok düzlemli modeller ve üsluplar, temsil ve iletişim için kullanım kapasitesine sahiptir". Bu anlamda, iletişimde görünen dilin dışında, arka planda çalışan çok düzlemli bağlamsal kodlar devreye girmektedir. 
Çok düzlemli söylem analizi; çevrimiçi paylaşımlardaki vatandaş ve Suriyeli tasvirini, bilgi üretimi üzerinden iktidar kurulumunu çözümlemek için ideal bir yöntemdir. Sosyal medyadaki paylaşımlar; görsel ve işitsel öğelerle birlikte metinlerin de olduğu çok düzlemli multimedya ürünleridir. Araştırma sorusuna yanıt aramak için bu makalede çoklu ortam verileri ele alınmaktadır. Türkiye'deki Suriyelilere dair görseller aracılığıyla yapılan değerlendirmeler ve bu değerlendirmeler ile yaratılan gruplaşmalarda görsellerin oynadığı rol, metinsel paylaşım öğeleri de dikkate alarak araştırılmaktır. Buradaki amaç, görselin kavramsallaştırılmasını sosyo-kültürel olarak temellendirmektir (Mitchell, 1984). Michel Foucault; sosyal yapıların dilin kullanımı için çeşitli kurallar oluşturduğunu ve bu kuralların, bireylerin sosyal yapı ve anlam arasında bağ kurmasına etki ettiğini dile getirmiştir (aktaran Çelik ve Ekşi, 2008). Görsel iletişim pratikleri, izleyiciyi belirli tür değerler hakkında düşünmeye teşvik etmektedir. Burada Suriyelilere ilişkin söylemi kuranlar olumlu ve olumsuz temsillerle ve referanslarla delil sunmaktadır. Sözgelimi, kullanıcıların belli biçim ve içerikleri; popüler kültür öğelerini ve üslupları veya gönderileri kullanarak belirli bir söylem üretmekte ve bu söylem, belirli kesim veya kişilerin topluma katııımı veya dışlanması için meşruiyet sağlamaktadır (Hyland ve Paltridge, 2013: 49). Bu inceleme, Alison Young'ın (2010) belirttiği gibi imgenin ve sosyal dünyanın birbirinden ayırt edilemeyeceği üzerine kurulmuştur. Şüphesiz, internette karşılaştığımız bir görseli yorumlarken deneyimlediğimiz gerçeklik ile karşılaştırıyoruz, yani deneyim önceden sosyo-kültürel, ekonomik ve politik dolayımlarla algılanan görseller aracılığıyla filtreleniyor (Eco, 1995); dolayısıyla görüntüler halihazırda var olan önyargıların pekiştirilmesinde önemli bir rol oynuyor.

Türkiye'deki Suriyeli mülteciler aleyhindeki yaklaşımları incelemek için \#ülkemdesuriyeliistemiyorum ve \#suriyelilerkardeşimizdir hashtag'leri altında paylaşılan görseller, nitel yöntemle kategorize edilmiştir. Bu iki ayrı hashtag altında paylaşımda bulunan kullanıcılar, üyelik bazında bir topluluk olarak tanımlanamaz (Kozinets, 2010) iseler de Türkiye'deki Suriyeli mültecilerin sorunlarıyla ilgili kutuplaşmış sosyal müttefiklerdir. Araştırmanın ilk aşamasında, Ekim 2018-Ekim 2019 tarihleri arasında Twitter'dan meta verileriyle birlikte görüntüler toplanmış, tekrarlayan iletilerin ayrılması 
sonucunda hareketsiz ve hareketli toplamda 50 adet görüntü analize dahil edilmek üzere veri setleri olarak dosyalanmıştır. Türkiye'deki Suriyeliler hakkında olumlu ya da olumsuz görüşleri aktarmak için paylaşılan bu görüntüler, tekrarlayan estetik özelliklerine ve temalarına göre kategorilere ayrılmıştır. Estetik özellikler; görsel kompozisyon özellikleri, yapım teknikleri, içerik özne ve objeleri ve bunların kültürel referansları çerçevesinde ele alınmıştır. Çalışmada, kullanıcıların öne sürdükleri iddiaları desteklemek için kullandıkları görüntülerde amatör çekim estetiği kullandıkları, karşıtlık kuran görselleri bir arada kullandıkları, Suriyelileri mazlum olarak tanımlamak için onları çeşitli yollarla estetize ettikleri, oryantalist referanslar kullandıkları ve kaotik bir topluluk olduklarına dair ürettikleri söylemi desteklemek için Suriyelileri kalabalık topluluklar halinde gösteren görüntüleri kullandıkları ortaya koyulmuştur.

Çalışmada taranan kullanıcı profilleri anonimleştirilerek analiz edilmiştir. Çevrimiçi alan paylaşımlarında bulunanlar, bu gönderilerin topluma açık olduğunun ve bu nedenle de toplanıp iletilip tekrar yorumlanabileceğinin bilgisine sahiptir (Walther, 2002). Öte yandan çevrimiçi alanda kullanılan takma adlar, gerçek adlar gibi çalışır ve gerçek adlar gibi ele alınmalıdır. Dolayısıyla kullanıcı adları, "Suriyeli karşıtı" veya "Suriyeli taraftarı" tanımlanması durumunda ötekileştirilebileceğinden risk altında kalmamaları için anonimleştirilmiştir.

\section{Görsel ve Hakikat}

Görsellik ve gerçek bilgi arasındaki ilişki Platon'dan beri tartışılmaktadır ve bu tartışma bugünkü post-hakikat ve iletişim tartışmasının ana temalarını da içermektedir. Çünkü Platon'un idealize ettiğinin tersine "yüksek teknoloji iletişimi ile duyusal ve algısal dünyanın, anlayışımızdaki etkileri daha da artmıştır" (Papacharissi, 2014: 9). Akıllı telefonların görüntü, ses ve video barındırma özelliklerinin giderek artmasıyla; görselişitsel materyallerin, son dakika haberlerinin, söylentilerin ve yorumların sosyal medya platformlarında paylaşılabilmesi, krize neden olan olaylar sırasında özellikle önem kazanmıştır (Bruns ve Hanusch, 2017: 1123). 
Bugün post-hakikat döneminde -Foucault'nun öne sürdüğü gibi iktidara bağlı kalmaya devam etse de (2001: 130)- hakikat rejimlerinin hâkimiyeti; Platonik objektiflik ve evrensellik tanımından öte, "kitlesel anlamda katılım ile sağlanabilecek görünürlüğe intiyaç duymaktadır" (Harsin, 2015: 329-330). Bu anlamda da iktidar, yeni katılımcı bilgi yayma teknolojilerinden yararlanmaktadır. Bilginin meşruiyeti; Senja Post'un (2014) tabiriyle, "gazetecilikte önyargısız sunuma, akademide sistematik kanıt ve yöntem gösterimine, yapısalcı yaklaşım tarafından da toplumsal mutabakata dayalı olmak" (aktaran Fahy, 2018: 5) ile koşullanırken her seferinde bu farklı disiplinlerin bilgi üretim geçerlilikleri, toplumun iletişim teknolojilerine ve kullanım araç ve şekillerine bağlıdır. Twitter ve Facebook gibi sosyal medya platformlarının ortaya çıkışı, sıradan kullanıcıları medyayı yönlendirme ve belirli konularda gündem yaratma (agenda setting) konusunda yetkilendirmiştir. Duyguları harekete geçiren (affective) görüntüler ise kitlesel katılımı sağlamak için araç olur; kişisel ve duygusal ifadeler, haber üretiminde görünürlük sağlanması için katıımcı desteği arar. Görüntülerin duygusal ve yaratıcı iletişimi, görsel olarak tanımlanan çağımızın tipik özelliğidir ve bilginin hızlı ve yoğun olarak gönderim ve alımında görselliğe odaklanmak medya okuryazarlığını kolaylaştırmaktadır. Metinlere göre daha yaygın bir şekilde izlenip paylaşılan imgeler, izleyicinin olayları yorumlama biçimini etkileme potansiyeline sahiptir (Bruns ve Hanusch, 2017: 1123). Televizyon, gazete, dergi ve geleneksel medyayı da yönlendirebilen kullanıcı temelli interaktif sosyal medya; görüntü tabanlı haber, görsel-işitsel mesaj, söylem destekleyici veya oluşturucu argümanlar olarak klipler, mem, GIF ve video gibi iletişimi etkileyen bilgi arabulucularını yoğun olarak kullanmaktadır. Günümüz iletişiminin görsel imgeye güvenmeye dayalı olması, metinsel iletişimdeki kayda değer azalmayla örtüşmektedir. Papakostas'a göre bunun nedeni; kişisel ve somut olanın, mesajı, yazılı metin ve soyut fikirlerden daha kolay iletmesidir (2016: 156).

Amatör ve profesyonel haberci ayrımının yok oluşu; gerçeğin doğru, objektif, önyargısız ve tarafsız iletimine olan güvenin kamuoyunda kaybedilmesi ve "uzmanlaşmış kişilerin, akademisyenler, uzmanlar, danışmanlar ve benzeri profesyonellerin hem maddî hem de ideolojik olarak daha geniş yapılarla bağlantılı algılanmasıyla" (de Guevara ve 
Kostić, 2017: 4) ilişkilidir. Bu anlamda, sübjektiflik bağlamında; sosyal medya içerik üreticileri, izleyici oranlarını yükseltmeyi amaçlayan kurumsal medya yayıncılarından farklı varsayılmamaktadır. Sübjektif ve objektif ayrımının silikleşmesine paralel olarak sosyal medya, genel ve özel konu ve alanlar arasında net bir ayrım yapmayı imkânsızlaştırmıştır (Papacharissi, 2010). Sosyal medyada imge üretim ve manipülasyon teknolojilerinin "her daim" (Hand, 2012) gündelik kullanımıyla beraber, imge üretimi artık amatör kullanıcıların da erişimindedir. Sosyal medyanın görsel estetiği doğruluk, orijinallik veya haber kaynağı gibi bilgiye ilişkin değerleri değiştirir, geliştirir veya belirler (Highfield ve Leaver, 2016: 52). Çevrimiçi kamusal alanda bilgi görünürlüğünü sağlayan "toplanma" (swarming) ve yaygınlaştırma, kalıcı olmayan sosyal oluşumlardır. Gündelik "görüntü bombardımanına" (Baudrillard, 1994) maruz kaldığımız iletişim çağında, katılımcının fark edilmek ve bilgi üretmek için sosyal medyada diğer kullanıcıların katılımına ihtiyacı vardır. Kullanıcılar, kendi sosyal medya hesaplarını kullanarak doğrudan izleyicilere ulaşabilirler ve bu anlamda katılımcılar; haberi, mesajı, uygun kanalları ve içeriği edindiyse kamuoyunu daha kolay harekete geçirebilir (Jowett ve O'Donnell, 2011: 395). Posthakikat kavramı ile tanımlanan günümüzde, sosyal medya katılımcısının görsel kullanımı ve görseli delil olarak sunması, post-hakikat sorunsalının ana birleşenlerindendir.

\section{Suriyeli Algısı ve Temsili}

Post-hakikat çağının önemli bir özelliği, her kullanıcının "gerçeği taşıma kapasitesi”ne sahip olması ve böylece uzman olmayan sıradan bir kullanıcının Facebook, Google veya Twitter üzerinden algoritmik olarak seçilmiş haber kaynaklarını, mevcut önyargıları pekiştirerek yayınlayabilmesidir (Peters, 2017: 564). Türkiye'deki Suriyeli imgesi üzerinden yapılan paylaşımlarda, halihazırda geçerli olan önyargıların bilgi üretiminde esas olduğuna dair sav, post-hakikat ile açıklanabilir. Post-hakikat çağında öne sürülen, gerçeklerden ziyade kişisel inançların ve duyguların hâkimiyetinin olduğudur. Yalnızca profesyonel gazeteci veya basın kuruluşlarınca paylaşılan görsellerde değil; amatör sosyal medya kullanıcısı olan, vatandaş gazeteciliği yapan kişilerin çevrimiçi alanda paylaştıkları görsellerde de Suriyelilerin nasıl temsil edildiğinin sorgulanması önem 
taşımaktadır. Sosyal medya platformları sayesinde bireyler ve kuruluşlar, geleneksel kitle iletişim araçlarına başvurma gereği duymadan hedef kitleleriyle etkileşime girebilmektedir (Seo ve Ebrahim, 2016: 4).

Görseller, Türkiye'de misafir olarak algılanan Suriyeli sığınmacıların konumunun meşruluğunu yitirmesine veya meşruluk kazanmasına katkı sunabilmektedir. Türkiye toplumu, Suriyelileri öncelikle "zulümden/savaştan kaçan mağdur insanlar" olarak tanımlamayı tercih etmiş; ancak bunu takip eden tanımlamalar ("bize yük olan insanlar", "bize ileride çok sorun açacak tehlikeli insanlar", "dilenciler/sadece yardımlarla yaşayan insanlar", "bizden oldukça farklı ve bize yabancı insanlar"), hem kaygıları hem de yaygın ötekileştirmeyi ortaya koymuştur (Erdoğan, 2017: 18). Sosyal medya kullanıcılarının Türkiye'de geçici koruma statüsündeki Suriyelilere ilişkin temsillerinin çoğunlukla olumsuz olduğu ve Suriyeli mültecilerin Türkiye'de geleceğe, huzura, ekonomiye ve sosyal yapıya karşı bir tehdit olarak algılandığı görülmektedir (Bozdağ ve Smets, 2017; Özdemir ve Öner-Özkan, 2016; Taş ve Taş, 2018). Yazılı basında, koruma altındaki Suriyelilerin temsil içinde inşa edilmiş konumlarının "kendisine yardım edilen", "kendisi hakkında konuşulan" vb. olarak nesneleştirildiği saptanmıştır (Efe vd., 2017: 21-22). İbrahim Efe vd. (2017: 86); Türk yazılı basınındaki fotoğrafların yalnızca yüzde 6'sında Suriyelilerin sıradan insanlar olarak temsil edildiğini, dolayısıyla sığınmacıların belirli bir sosyal gruba ya da kimliğe indirgenmeden, izleyenle eşit şartlara sahip bireyler olarak temsil edilmediğini belirtmektedir. Zorunlu göç ile gelen Suriyeli sayısının az ve çok olduğu ülkelerin sosyal medya haberlerini karşılaştıran bir çalışmada, aralarında Türkiye'nin de olduğu çokça göç alan ülkelerin haberlerinde Suriyelilerin "sel”, "dolu”, "akış”, "kabarma", "dökülme", "damlama" gibi metaforlarla tasvir edildiği saptanmıştır (Abid vd., 2017: 138).

Bu noktadan sonra, Türkiye'deki Suriyelilerin statüsü hakkındaki görsellerinin ortak ve ayırıcı temaları; dayanışma, acıma, aleyhtarlık, antipati veya ilgisizlik gibi durumları tanımlayan görsel öğe ve prensipler ile çevrimiçi görüşlerin, tepkilerin ve beyanların ilişkisi sorgulanacaktır. 


\section{Sosyal Medyada Suriyeli İmgesi}

\section{Amatör Çekim Estetiği}

Sosyal medya katılımcıları arasındaki iletişimde objektiflik göstergesi olarak varlığı fark edilmeyen gözlemci (fly-on-the wall) çekim tekniği, amatör olarak kullanılmaktadır. Bu çekimlerde, habere kendi bilgisi olmadan, şans eseri tanık olarak cep telefonu kamerasıyla çekim yapmaya ve profesyonel foto-muhabirliğinde olanın aksine çözünürlüğü düşük video ve fotoğraflara rastlanmaktadır. Bu görüntülerin efektsiz ve kurgusuz oluşu, görüntünün objektif gerçeklik kaydı olduğu iddiası ile örtüşmektedir. Çekimler, olayın yaşandığı alanı yüksekten bakan bir açı ile gözlemlemektedir. Biri Suriyeli göçmenleri destekleyen (Görsel 2), diğeri Suriyeli göçmen karşıtı olan (Görsel 1) aşağıdaki iki çekim de video başlangıç ve bitiş jenerik öğeleri taşımayan ve gözlemcinin ses ve vücut hareketini çekime yansıtan görüntülerdir. Aşağıdaki video imajı (Görsel 1) paylaşımında çekimin Florya sahilinde yapıldığı ve kameraya yansıyan kişilerin "15-25 yaşlarındaki 'mazlum' Suriyeli gençler" olduğu ve "nargile önünde dans" ettikleri ve "karpuz yeme yarışması" yapıp "kabukları güzelim, tertemiz sahile attıkları" iddia edilmektedir. Söz konusu paylaşımda ayrıca Suriye'de görev yapan Türk askeriyle burada "Suriyeli" olarak tanımlanan gençler arasında, "bunlar böyle keyif çatarken bizim evlatlarımız, Suriye'de şehit düşüyor," yorumuyla karşılaştırma yapılmaktadır. Video kaydında amatör odaklanma ve kamera hareketleri bulunmaktadır. Ancak video kurgulanmış; "karpuz yeme", "nargile önünde dans" gibi anlatılan hareketler sıraya sokulmuştur. Objektiflik iddiası olan bu çekim tekniği, Türkiye toplumunun Suriyeliler üzerindeki gözetim pratiğini göstermektedir. Amatör çekim, kayıt cihazının ve kullanıcı paylaşımının gerçekliğinin samimiyetini yansıtır. Ayrıca paylaşımdaki videolar, kayıt yapanın vücut hareketini ve yaşadığı deneyimi de yakalamaktadır. Bu çekimlerde, bir cep telefonu kamerasıyla çekim yapmak, gönderenin tarafsızlığını geri kazanan bir şahit olarak konumunu güçlendirir. Basit kurgu veya bulanık görüntü, kayıt yapanın profesyonel kurgu yapamadığı ve bu nedenle mesaj göndericinin tarafsız ve orijinal bir görüntüyü paylaştığı iddiasını destekler. Profesyonel olanlardan farklı olarak düşük çözünürlüklü 
video veya fotoğraf kullanımı burada, Sara Ahmed'in deyimiyle "mahalle gözetimi" (neighborhood watch) (Ahmed, 2000) olarak adlandırılabilir. Mahalle gözetiminde suç unsurlarını gözlemleyen özne; mahallesinin mülkiyet ve sosyal imtiyazlar gibi değerlerini, saldırılara ve davetsiz misafirlere karşı koruyarak sınırları belirler ve yabancıyı belirleyen kategorileri üretir (Ahmed, 2000: 27). Söz konusu örnekte, Türkiye'deki Suriyelilerin, Türkiye vatandaşlarının maddî veya manevî değerlerine zarar verdiği iddia edilmektedir.

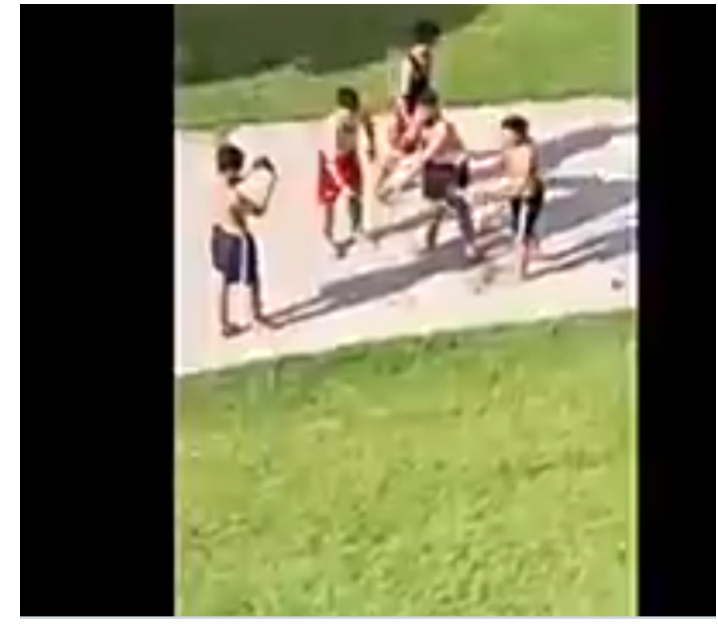

Ł】 709

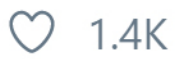

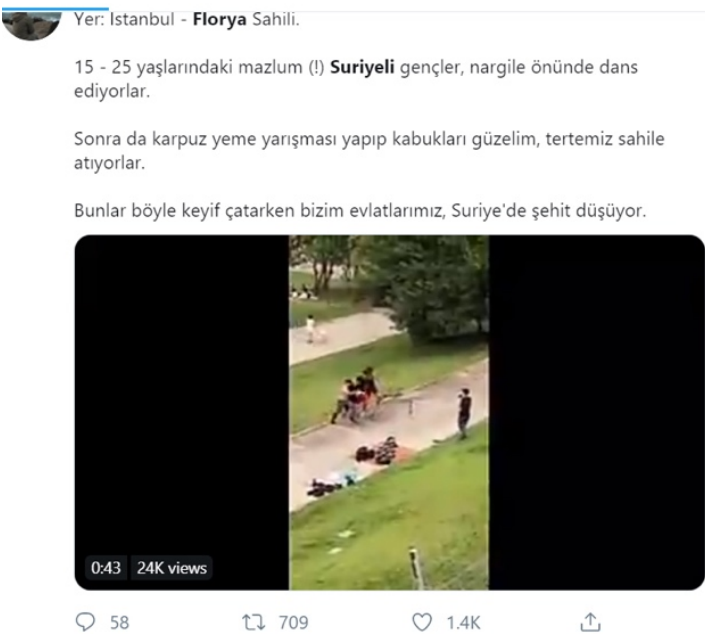

$\uparrow\urcorner 709$

O $1.4 \mathrm{~K}$

Görsel 1: Amatör kamera teknikleri kullanımı Twitter paylaşım örneği görselleri. Son görüntülenme tarihi: 19.10.2019

Suriyelilere sempati ile yaklaşan diğer paylaşımda, videoda gözüken bir Türk'ün Mersin'de bir sitede, daha sonra Afgan olduğu belirtilen "Suriyeli bir çocuğa tokat attığı" ve annesini de darp ettiği gösterilmektedir. Daha sonra çıkarıldığı mahkemede ev hapsi cezası alan zanlının hareketi, bu paylaşımda "ırkçı" ve "insanlık dışı" olarak tanımlanmıştır. Video çekiminin cep telefonuyla bir balkondan yapıldığı ve amatör kamera çekimi olduğu anlaşılmaktadır. Video, çekenin balkondan uzaklaşmasıyla son bulmaktadır. Daha sonra konuyla ilgili diğer paylaşımlarda bu çekimin görüntülerine söz konusu tokat hareketini vurgulayan kırmızı çizgiler eklenmiştir. Prem Kumar Rajaram, kadın ve bebek görselinin mültecilere yardım amaçlı kullanımını Batılı kültürün, kadın ile güçsüzlüğü ve dolayısıyla zararsızlığı bağdaştırması olarak yorumlamıştır (Rajaram, 2002: 251). Mülteci tasvirinde görsel kullanım değişikliklerine dikkat çeken Johnson, II. 
Dünya Savaşı sırasındaki Avrupalı mültecilerinin politik duruşlarının ön planda olduğunu; ama bugün devam eden mülteci tasvirinde drama unsurlarının kimliksizleştirme (depersonalisation) belirttiğini ve mülteciliğin "küresel güney küreden olmaya, fakirlik veya savaştan kaçmaya" indirgenmesine neden olduğunu ifade etmiştir (Johnson, 2011: 10211022). Şiddete maruz kalan çocuğun annesinin darp edilmesi, burada yine Suriyelilerin mazlum olduğu iddiasını desteklemekte kullanılmaktadır; çünkü eşit şartlardaki taraflar arasında bir münakaşa gerçekleşememiştir.

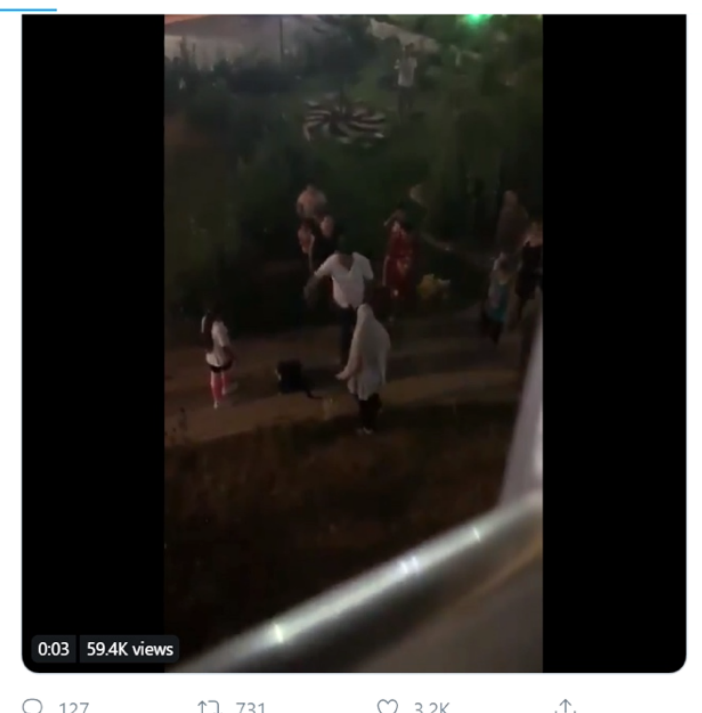

Görsel 2: Amatör kamera teknikleri kullanımı Twitter paylaşım örneği. Son görüntülenme tarihi: 20.10.2019

Buradaki iki ayrı görüşün dayanağı da objektiflik iddiası olan video çekimleridir. Bu temsil biçimi; toplumu, talihsizler ile bu talihsizlerin sefaletini doğrudan ya da dolaylı olarak gözlemleyebildiği için şanslı olanlar olarak iki ayrı sınıfta kategorize eder. Suriye'den zorunlu göç ile gelenlerle kurulan misafir ilişkisinin tam da bu nedenle kaygan bir zeminde yer alması; Suriyelilerin, ev sahibinin yani yerleşik toplumun üyelerinin iyi niyetine bağımlı kişiler olarak temsil edilmesine yol açmaktadır. Dolayısıyla misafir-ev sahibi ilişkisi üzerinden kurulan Türkiye'deki Suriyeliler ve yerleşik halk ortaklığı; modern hak temelli, sözleşmeye dayalı ilişkilerden farklıdır (Atasü-Topçuoğlu, 2019: 5). Arendt'in "merhamet politikası" olarak betimlediği acı gösterisi (Arendt, 2006) ve bu gösterinin seyrine dayanan bu türden bir toplumsal paylaşım, eyleme dayalı politikadan ayrılır. Bu açıdan 
bakıldığında insanlığın ortak değerlerine bağlı merhamet temelli bildirimler, göçmen ve yerleşik topluluk üyeleri arasında sosyal, politik ve ekonomik sıkıntılara dayanan mahrumiyette rekabet yaratabilmektedir. Acımaya dayalı göçmen kabulü, beraberinde mağduriyetin sürekli olarak ispatlanmasını gerektirdiğinden sosyal medyada görsel kullanımı, fikir beyanı ve kanıt gösterimi için kullanılmaktadır. Halbuki eyleme dayalı "adalet politikası", vatandaşların haklarını tanımlayan ve değerlendiren ortak bir adalet anlayışı hesaba katarak ihtilafları adil sonuçlara vardıracak başarılı bir uyum öngörüsüdür (Boltanski, 1999: 3-4). Bu nedenle merhamet politikası yerine, yine Arendt'in (2006) tanımladığı adalet politikasına geçilmesi ve Türkiye'deki Suriyelilerin varlığının mazlumluklarına değil, hak temelli yargıya dayandırılması; tartışmanın gösteri politikasından ileriye götürülmesini mümkün kılacaktır.

Türkiye toplumu, Suriyelileri savaştan kaçan mağdur insanlar olarak tanımlamış; ancak sonrasında, "ileride çok sorun açacak tehlikeli insanlar; sadece yardımlarla yaşayan insanlar; bizden oldukça farklı insanlar" gibi ifadelerle ötekileştirmiştir (Erdoğan, 2017: 18-19). Bunun en önemli örneklerinden biri, yine Taksim'de yılbaşı kutlaması yapan Suriyeli grubuna ait görüntülerin sosyal medyada, "Suriyelileri istemiyoruz" başıı̆ı altında kınanmasıdır. 31 Aralık 2018'de, İstanbul Taksim Meydanı'nda, yılbaşı gecesini Suriye bayraklarıyla kutlayan bir grup Suriyelinin fotoğrafları; Türkiye'deki Suriyelilerin sığınmacı statüsünü hak etmedikleri, çünkü acı çekmedikleri, yeni yıl kutlamasının keyfini çıkardıkları yorumuyla beraber sosyal medyada paylaşılmışı ır (Deutsche Welle, 2019). Yine 2019'da Ramazan Bayramı'nı kutlamak için ülkelerine geri dönen Suriyelileri gösterilen videoda, bayram nedeniyle yapılan bu yolculuk, Suriyelilerin statülerini kötüye kullanması olarak yorumlanmıştır. Video; Suriyelilerin, tatilde aile ziyaretleri için, anavatanları olan Suriye'ye güvenli bir şekilde, hiç tehlike hissetmeden geri dönebileceğinin kanıtı olarak sosyal medyada kullanılmıştır. Suriye'deki talihsizliklerinin ve can güvenlikleri olmadığı için Türkiye'de koruma altında oldukları iddialarının geçersizliğinin kanıtı olarak öne sürülen video, Suriyelilerin Türk misafirperverliğini suiistimal ettikleri iddiasını desteklemek için kullanılmıştır. 1951 Mülteci Sözleşmesi uyarınca mülteci; "Irk, din, uyruk, belirli bir sosyal gruba üye olma ya da siyasî görüşü 
nedeniyle zulüm görme gibi sağlam temelli olan korkuları nedeniyle ülkesine geri dönemeyen ya da geri dönmek istemeyen kişi” (Birleşmiş Milletler Mülteciler Yüksek Komiserliği) olarak nitelendirilmiştir. Her ne kadar Türkiye'deki Suriyeliler mülteci olarak değil, geçici koruma altındakiler veya daha öncesinde "misafirler" olarak tanımlansa da bu görüntüler, Suriyelilerin "kurban" olmadıklarını kanıtlamakta ve bu nedenle de Türkiye vatandaşlarının merhamet göstermesine gerek kalmadığını belirtmekte kullanılmaktadır. Çünkü acımaya dayalı göçmen kabulü, mağduriyetin sürekli olarak ispatlanmasını şart koşmaktadır. Dolayısıyla mazlumluk gösterisi, Suriyelilerin Türkiye'deki konumlarının devamlılığı için sürekli gösterimde olmalıdır. Suriyelilerin Türkiye'de kalmalarına karşıt olan taraf da aynen Suriyelilere destek olan paylaşımlarda olduğu gibi görsellerde mazlumluk üzerinden karşıt görüş sunmakta ve Suriyelilerin, Türklerin merhametini hak eden bir mazlumluğa sahip olmadığını ileri sürmektedir.

\section{Karşıtık Kuran İki Görselin Bir Arada Kullanımı}

Yukarıdaki görüntülerde "mazlum" olan ve bu nedenle de "yardım edilebilir" Suriyeliler ile Türkiye vatandaşları arasındaki karşıtlık yansıtılmaktadır. Farklı görüşler olarak tanımlanabilecek bu iki paylaşımda görüntü, "mazlum" olanı tespit edip bunu iletme gayesiyle kullanılmaktadır. Bu yaklaşıma dair en çok karşımıza çıkan, karşıtlık gösteren iki resmin yan yana yüklenmesiyle oluşan veya direkt olarak kolaj çalışması şeklinde hazırlanan görsellerdir. Bu tür görsel kullanımında, yukarıdaki örneklerdeki gibi "tarafsız gözlemci tanık" görseli yerine karşıtlık yaratımı ve bu karşıtlığın belirginliğini "gören ve gösteren" bir iddianın paylaşımı söz konusu olmaktadır. Bu tür mesajlar açık bir şekilde tercihini belirtmektedir. Bu formun ortak özelliği, takdir edilen bölümün veya parçanın daha yüksek kontrast değerli veya dramatik bir etki vermesi amacıyla filtre uygulamasıyla renginin düzenlenmesidir. Bu şekilde görsel; çıplak gözle bakıldığında açıkça anlaşılmayan ama aslen aldatıcı olduğu düşünülen görüntünün altında saklı olan anlamı, gözler önüne sermeyi amaçlamaktadır. Bu görseller, fiziksel dünyada duyularla algılanamayan (supersensible) deneyimleri somutlaştırmaktadır. Dolayısıyla rötuş teknikleriyle (photoshop vb.) kurgulanmaktadır. Görsel vasıtasıyla "gerçekliği yakalama", 
başka bir deyişle "tıklama deneyimi" (click experience) sunma, amaçlanmaktadır. Bu formu tekrarlayan paylaşımlar, Türkiye'deki Suriyelilerin Türk devletinin ve Türk toplumunun merhametini hak etmediğine ilişkin "görünmez gerçeği" ortaya çıkarma iddiasındadır.
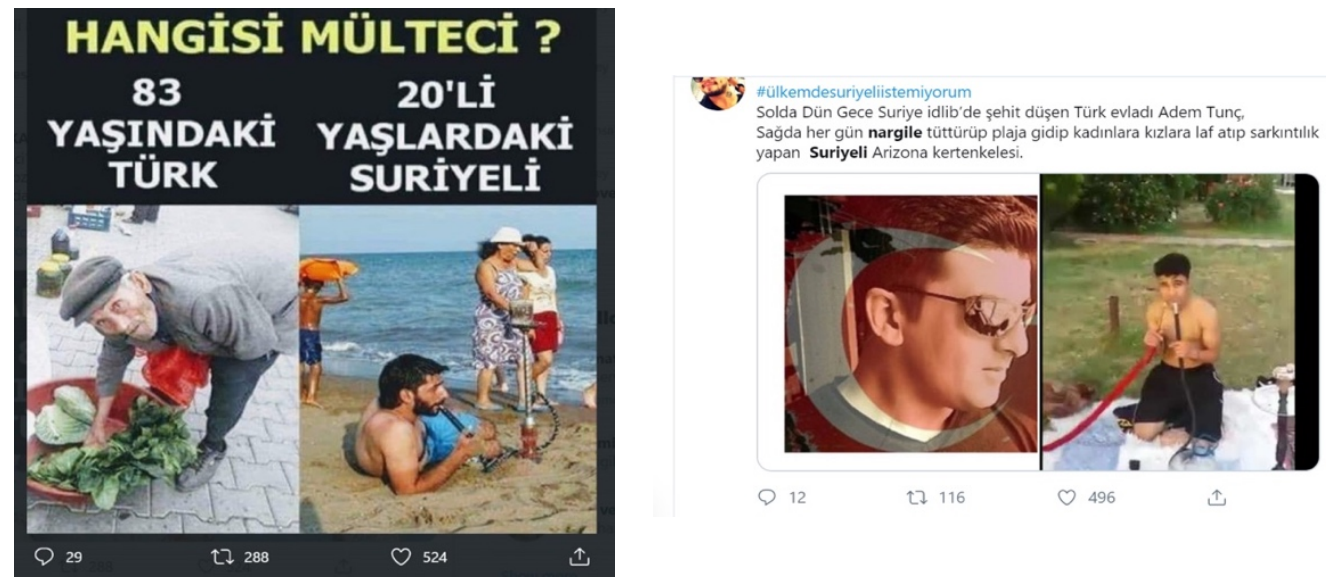

Görsel 3:“Click” deneyimi ve kıyaslama teknikleri kullanımı Twitter paylaşım örnekleri. Son görüntülenme tarihi: 08.11.2019

Tıklama deneyimini, aniden ortaya çıkan ve olayın önemini ve duygusal derinliğini (epiphany) kavramaya yarayan küçük detay olarak tanımlayan Carol Brooks; bu deneyimi fiziksel duyuma bağlamaktadır (Renshaw, 2002: 63). Burada, paylaşımı yapan, "normalde görülemeyen" veya "olağandışı" (deviant) durumu görsellerle anlatma iddiasındadır. "Mazlum sığınmacı Suriyeli" ile ona yardım etmesi gereken "vatandaş Türk" ilişkisi bu yolla çürütülmektedir. Fotoğrafçının yakaladığı an, sözde merhameti suiistimal edip plajda gezinen Suriyelinin görselidir. Bu görsel sayesinde "kavrama ve çözme" (epiphany) deneyimini paylaşan kullanıcı, yaptığı karşılaştırmayı yaymaktadır. Söz konusu olan yukarıdaki fotoğraflarda (Görsel 3) çalışma, üretme veya vatanî görev addedilen askerlik yerine boş zaman geçiren veya "tembel" olma lüksüne sahip kişi, "mazlum" sayılmamaktadır. Bu görsellerde (Görsel 3), mazlum ve muhtaç olmadığı gösterilen Suriyeliyle mukayese edilen Türk, askerlik -vatandaşlık-görevini yapan veya 
yaşlılık gibi kendisini muhtaç bırakacak bir nedene sahip olmasına rağmen devletten yardım almayandır.

\section{Mazlumun Estetize Edilmesi}

Türkiye'deki Suriyeli göçmen karşıtı ve destekçisi olarak betimlenecek görseller karşılaştırıldığında, Suriyelilerin iffet ve aile sahibi olup iyi Müslümanlık özellikleri taşıdıklarına dair kanıt olarak sunulan görseller ile Suriyelilerin adap ve ahlak gibi bilgilerden yoksun olduğuna dair görsellerin karşıt olarak kullanılması dikkat çekmektedir. Buradaki paylaşım görüntüleri, mazlumluk ve mazlumluk karşısında ailevî ve ahlakî değerleri sahiplenenleri estetize eden bir şekilde resmedilmektedir. Aşağıdaki görsellerde, başlarına gelen talihsiz savaş ve bunun getirdiği yokluğa rağmen Suriyeliler; şikâyet etme veya kaderlerine küsme lüksünden uzak, hayat mücadelesini aza kanaat ederek, aile ve inançla bezeli bir şekilde yaşıyor gösterilmektedir. Buradaki paylaşımlar da yine yoğun olarak kadın ve çocuk görüntüleri seçilmiş ve Suriyelilerin mazlum olduğu iddiasını desteklemek için kullanılmıştır. Suriyeli göçmenleri destekleyen paylaşımlarda toplumsal cinsiyete dayalı kasıtlı bir görsel seçimi ve dağılımı görülmektedir. Sefil, masum veya zararsız olarak kurgulanan ve bu nedenle de merhamet uyandırabilecek kadın ve çocuk görüntülerine, Suriyelilerin Türkiye'de kalmasını destekleyen paylaşımlarda sıkça rastlanmaktadır.

$\mathrm{Bu}$ yaklaşımı pekiştirmek için kullanılan, arkada bırakılan Suriye görüntüleri ise Melanie Joy McNaughton'ın "harabe pornosu" kavramı ile ifade ettiği, Detroit'in çürüyen yıkık binalarına dair estetik üslup ile benzeşmektedir. "Harabe pornosu" (ruin porn) (McNaughton, 2013) terimi, Detroit merkezli bir blog olan Sweet Juniper'ın yazarı ve fotoğrafçısı James Griffioen'e atfedilir. Griffioen; Detroit'in çökmekte olan altyapısının çekimlerini, bozulmaların çoğunun arkasındaki uzun tarih ve politikaları kabul etmeden, estetik bir arzuyu tatmin etmek için, ayrı ve sömürücü bir şekilde kullanan gazetecileri eleştirir. "Harabe pornosu" teriminden alıntı yapan McNaughton, "pornografinin sona ermek için bir araç olduğunu: ilişkiye girmenin değil, ego-merkezli zevk için bir fırsat" (McNaughton, 2013: 141) olarak işlevsizleştiğini ve sonuç olarak Detroit'in çürümesini 
gösteren bu fotoğrafların, Detroit’in durumu hakkında çözüm aramadığını belirtmiştir. Bu nedenle, harabe pornografisi görüntüleri; ilerlemesi durdurulamaz yıkımın en son raddesinde, pasif ve doğal yıkım gücünün tasvirinde kullanılmaktadır.

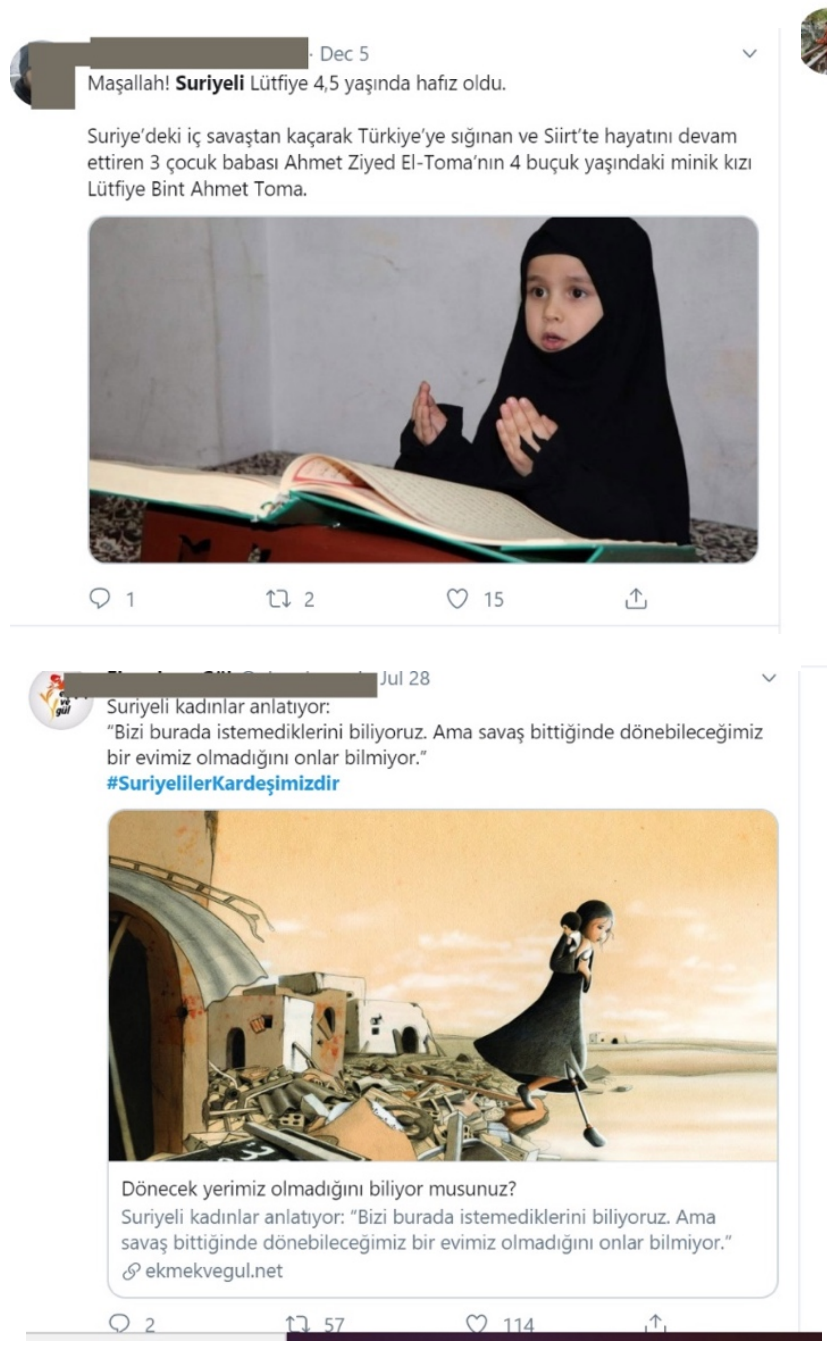

Müslüman Bir Ülkede Kuşlar Aç Kaldı Demesinler.....

/ Hz Ömer (r.a)

\#SuriyelilerKardeșimizdir

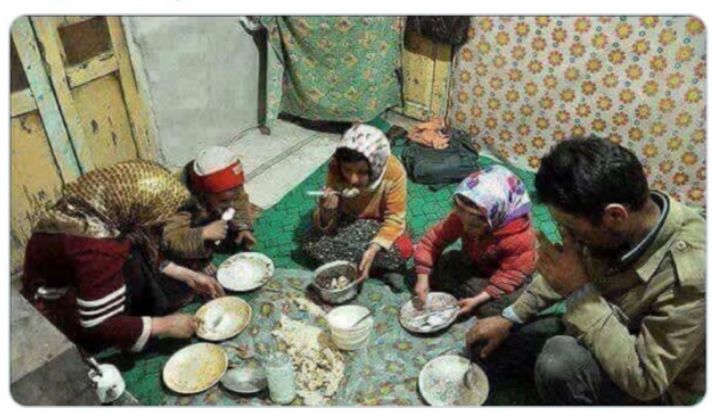

Q

ใ๖ 60

○ 132

$\uparrow$

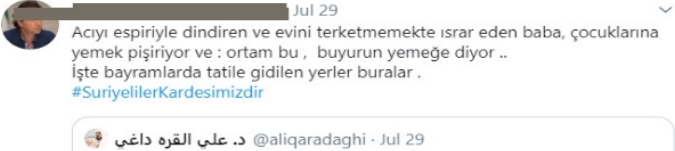

9aliqaradaghi · Jul 29

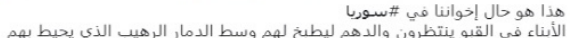

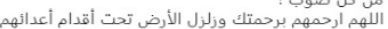

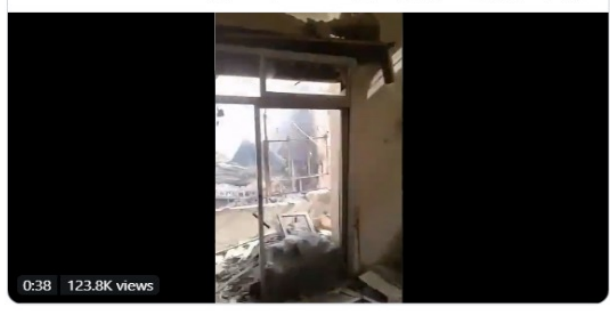

○ 4 ¿工 $32 \quad 044$ ث

Görsel 4: Türkiye'de Suriyeli destekçisi görsel kullanımı Twitter paylaşım örnekleri. Son görüntülenme tarih aralığı: Eylül-Kasım 2019

$\mathrm{Bu}$ tasvirlerde, insanın istenci ve yaratıcı kabiliyeti, başarısızlığa mahkûm olarak tanımlanmaktadır. Yani estetize edilen şehir harabesi tasvirleri, insanlık adına çözümsüz bir durumu temsil eder. Dolayısıyla paylaşılan bu görsellerde, "mazlum" Suriyelinin, Suriye savaşı ile ilgili nedensel veya ülkelerinin savaştan sonraki durumu ile ilgili dolaylı bir sorumluluğu veya failliği bulunmamaktadır. Bu anlayışa göre Suriye'nin durumu, mazlum Suriyeliden bağımsız olarak onun içine düştüğü ve doğal olmasa da insanın 
tabiatının sebebiyet verdiği bir hadisedir. Bu tasvirlerde "mazlum" Suriyeliler, savaş sonrası yine "kader" olarak betimlenen yurtlarından edilme durumlarını inanca sığınarak veya ailelerine tutunup paylaşarak geçirmektedir. Bu şekilde tasvir edilen Suriye yanlısı paylaşımlar, aynı zamanda izleyicinin bu görüntüleri gördükten sonra hâlâ Suriyelilerin Türkiye'deki statüsünü meşru bulmuyorsa iyi bir vicdanla donatılmadığını ve dolayısıyla iyi bir Müslüman olmadığını iddia etmektedir.

\section{Oryantalist Referansların Kullanılması}

Suriyeli göçmen karşıtı görsel paylaşımlarına ait söylemlerde Suriyelilerin mazlum olmadığı dile getirilir; çünkü bu bakış açısına göre Suriyeliler ahlaktan uzak, çalışma kültürü olmayan ve kamusal düzene aykırı hareketlerde bulunan kişiler olarak resmedilir. Bu tür görsel paylaşımlarında betimlenen Suriyeli erkekler, "yarı çıplak" veya fanila ve atlet gibi omuz ve göğsü açıkta bırakan giysiler giymiş olarak görülmektedir. Daha sonra bir Türk'e ait olduğu anlaşılan denizde nargile içen Suriyeli fotoğrafının (Şuşar, 2019) hızla yayılması, dünyadaki Oryantalist tasvir geleneğinin ve Türkiye'deki Arap sterotipleştirmesinin yarattığı kültürel çağrışımlarla ilişkilidir. Aşağıdaki örneklerde (Görsel 5), sahilde erkekler yarı çıplak olarak kalabalık bir şekilde bulunmakta ve emek gerektiren bir uğraş ile meşgul olmayıp sadece boş zaman geçirmektedir. Başka örneklerde (Görsel 5), kadınların genelde başı kapalı olarak ancak yine herhangi bir beceri, ustalık veya çalışma sayılmayan aktiviteler yaparken yer aldıkları görüntüler paylaşılmıştır. Bu paylaşımlar da, hem kapalı kadın hem de "yarı çıplak" erkek görüntüleri ve kamusal alandaki nizamları açısından, Arap/Doğu kültürü insanı prototipini Oryantalist bir üslupla çizmektedir. Dolayısıyla, bu görsellerdeki Oryantalist tasvir; Suriyelilerin ülkesiz kalmasının bir tesadüf veya şanssızlık değil, kendi kültürlerinin bir parçası olarak da nitelendirmektedir. Bu anlamda da bu görseller Suriyelilerin merhameti hak etmediğine işaret eder. 


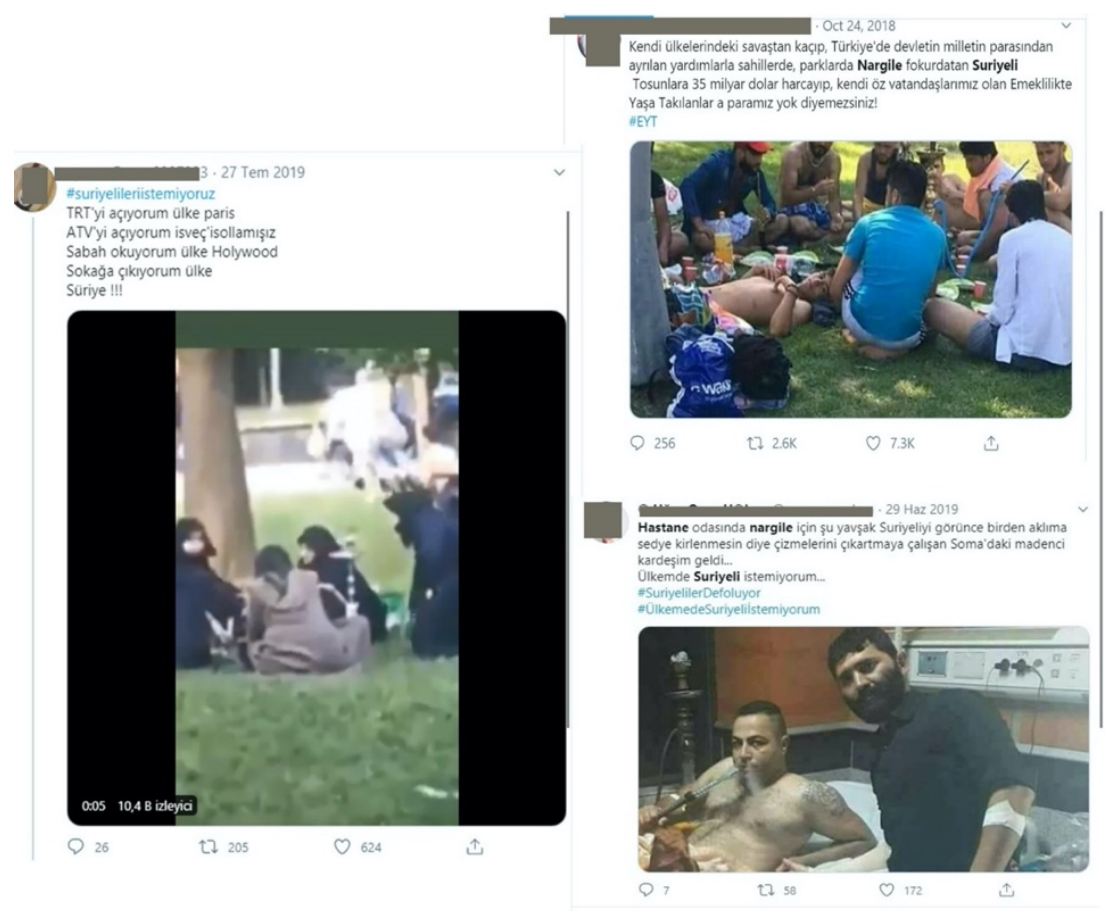

Görsel 5: Türkiye'de Suriyeli karşıtı görsel kullanımı Twitter paylaşım örnekleri. Son görüntülenme tarih aralığı: Aralık 2019

Edward Said; Oryantalizmi Batı kökenli bir söylem olarak tanımlamış ve Doğu hakkında açıklamalar yaparak, görüşlerini yetkilendirerek, öğreterek, yerleştirerek, onun üzerinde bilgi otoritesi kurmak olarak nitelendirmiştir. Said'e göre bu Oryantalist betimlemelerde, Doğulu olan mantıksız, düşkün, çocuksu, farklı ve mahrumdur; buna karşın Avrupa ve Batı, erdemli, olgun, normal ve rasyoneldir (2003: 40). Said, Lord Cromer ve A. J. Balfour'un Mısır kolonisi hakkındaki tasvirlerinde Araplara, egemen Batılı ırkın onları, onlardan daha iyi tanıdığını ve modern dünyada sadece çağdaş medeniyetler sayesinde düşkünlüğün sefilliğinden sıyrılarak üretken koloni sakinleri olunabileceğini (2003: 35); aksi halde inisiyatiften uzak, düzensiz zihinleri nedeniyle bir kaldırımda veya yolda yürümekten aciz, istilacı ve yalancı, aynı zamanda uyuşuk ve şüpheli olarak niteleneceklerini belirtir (2003: 39). Ancak Said, çalışmalarında Osmanlı İmparatorluğu'nun kendi içindeki ve daha sonraki dönemde Türklerin Araplara yönelik görüşü içindeki Oryantalizm konusuna değinmemiştir. Buradaki kolonyal Avrupalı ve kolonize edilmiş Arap toplumu karşıtlaştırmasına benzeyen Türkiye'deki Suriyelilere ilişkin görüntülerde, Suriyeliler üretken olmayan, kamusal alanda düzensiz ve huzur 
kaçırıcı olarak görüntülenmiştir. Buna paralel olarak Arap kadınların bir park alanında toplanarak nargile içtiğini gösteren sosyal medya videosuna (Görsel 5), "TRT'yi açıyorum, ülke Paris; ATV'yi açıyorum, İsveç'i sollamışız; Sabah okuyorum, ülke Hollywood; ama sokağa çıkıyorum, ülke Suriye," diyen bir metin eşlik etmektedir. Anaakım medyanın söyleminin aksine Türkiye'nin, Suriyelilerin varlığı nedeniyle Batı dünyasının bir üyesi olamadığını ifade eden metinde, bunun nedeni, Suriyelilerin kamusal ile özel alan arasındaki ayrımı ihlal etmeleridir.

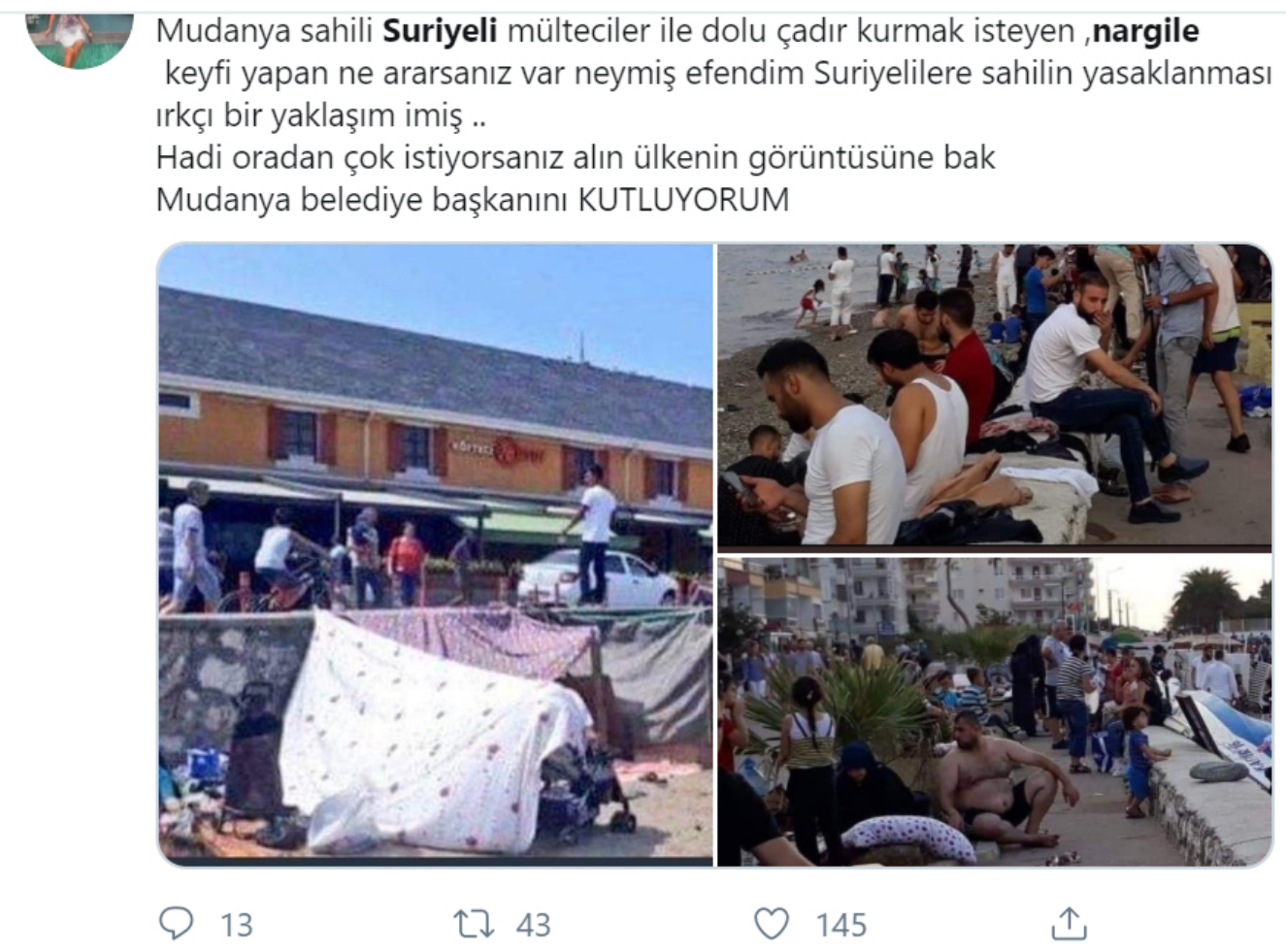

Görsel 5: Uyumsuzluğu belgeleyen Twitter paylaşım örnekleri. Son görüntülenme tarihi: 17.11.2019

Bu görsellerdeki düzensizlik; Görsel 6'da olduğu gibi kimi zaman farklı desenlerdeki örtü, çarşaf, giyim gibi öğelerin paylaşılan imajı kaplamasıyla da anlatılmaktadır. Bunun dışında mantıklı-mantıksız tezatlığı yine kamusal alan olan hastane gibi bir yerde nargile içmek veya sahilde çadır kurup pijamayla dolaşmak gibi yer ve o yere uygun hareketlerdeki uygunsuzluk betimlemeleriyle örneklendirilmiştir. Çıplaklığın Suriyeli erkeklerle özdeşleştirilmesi; Oryantalist tahayyül uyarınca Arap erkeğinin kamusal alanda 
uygunsuz, ilkel ve geri kalmış bir yapıda gösterilmesi olarak değerlendirilebilir. Bu tahayyül, Türk erkek ile Suriyeli erkek arasındaki farkı ve dolayısıyla sınırı da belirlemektedir. Suriyeli erkek; vatanını terk ederek askerlik görevini icra etmeyen, eğlenen ama çalışmayan veya üretmeyen ve bunlara ek olarak "ev hali" diye tabir edilen görüntüsüyle ideal, ataerkil, millî, çalışkan ve üretken özelliklere sahip olmayan kişidir. Öyleyse bu görsellere göre yine Suriyeliler ve özellikle Suriyeli erkekler, kendi vatanlarındaki düzensizlikten sorumludur ve aynı düzensizliği Türkiye'deki yaşamlarında da tekrarlamakta ve kendi hayatlarında aktif rol üstlenememektedirler.

\section{Kaotik Görsel Kullanımı}

Suriyelilere dair görsel kullanımında öne çıkan diğer temayı kaos olarak adlandırabiliriz. Bu tema içinde analiz edilen fotoğraflarda Suriyeliler kalabalık biçimde; kaos, düzensizlik, dehşet gibi negatif his ve çağrışımlar uyandıracak şekilde gösterilmektedir. Bu görüntülerin hem Suriyelileri tehdit olarak görenler tarafından hem de onlara sempati duyanlar tarafından kullanıldığı görülmektedir.
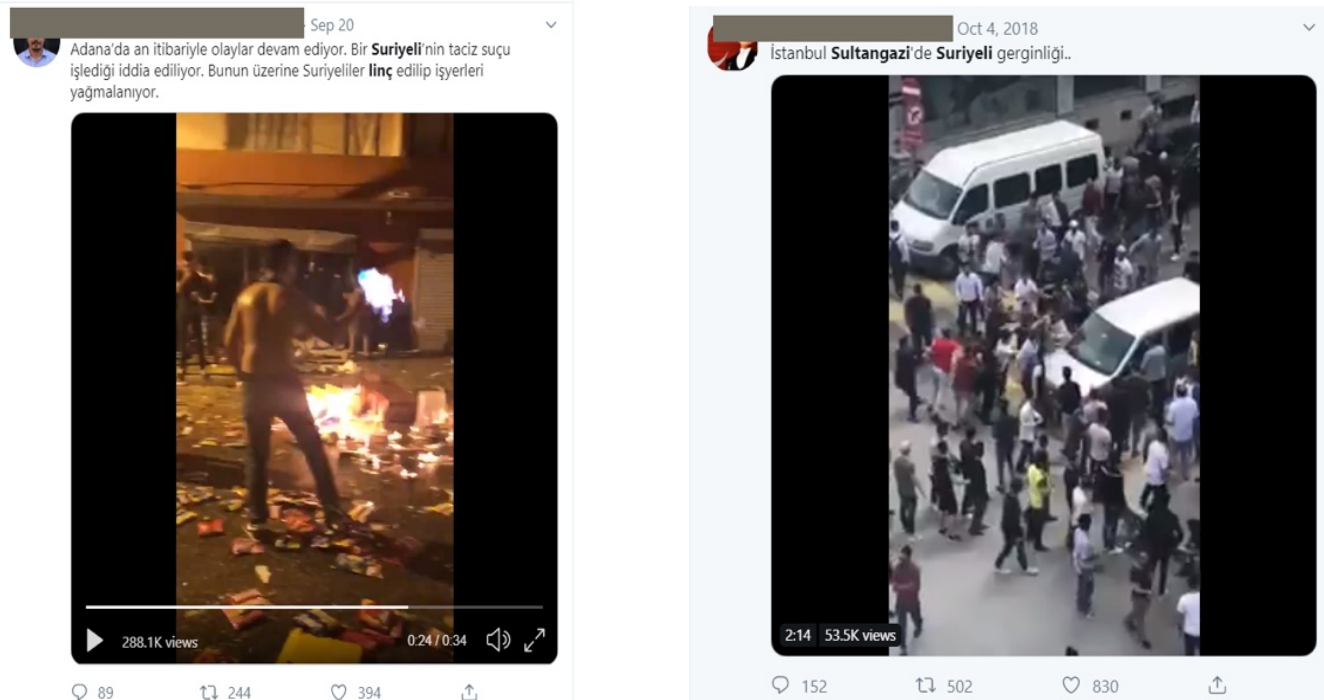

Görsel 7: Asayiş sorunlarını ve düzensizliği belgeleyen Twitter paylaşım örnekleri. Son görüntülenme tarih aralıkları: Ağustos- Kasım.2019

Suriyeli nüfusun yüksek olduğu mahallelerdeki linç girişimlerinin video kayıtları, bir asayiş eksikliğini vurgulamaktadır. Bu videolardaki kalabalık insan tasviri ve şiddet görüntüleri 
karşısında polis veya ambulans gibi imgeler, devlet kurum ve kuruluşlarına ait varlığı ifade etse de bu videoları paylaşan bir kesime göre devlet bu görüntülerdeki olayların cereyan etmesine engel olamamış ve aciz kalmıştır. Suriyeliler konusunda hem pozitif hem de negatif görüşe sahip görsel paylaşımlarda toplumsal dayanışma ve iletişim eksikliği tasviri hâkimdir. Linç vakalarının görüntüleri (Görsel 7); devletin meşru şiddet kullanımının ötesine geçen, güçlerin veya tarafların birbirleriyle çatışmasının veya gerek özel mülke gerekse kamu mülküne zarar verilmesinin önüne geçilemediğinin kanıtı olarak sunulmuştur. Bu görüntüler, Suriyeli imgesiyle birleştirildiğinden bir nevi Suriye ve Suriyeli durumunun, yani yurtsuzluğun ve devletsizliğin Türkiye'ye taşındığının göstergesi olarak kullanılmaktadır. Suriyelilerin kendi ülkelerindeki iç savaşın görüntülerine dair çağrışım yapan bu paylaşımlar, Suriye'deki savaşı Türkiye'ye taşıma tehdidini içermektedir. Dolayısıyla, merhamet politikasında birbirlerinden ayrılması gereken yardım eden ve büyüklük gösterenler ile muhtaç ve mazlum olan taraflar, Türkiye'nin Suriyeliler tarafından veya onların aracılığıyla karıştırılması intimalinin gündeme getirilmesi ile tersine çevrilmektedir. Çünkü sözde şanslı ve üstün olması gereken Türk tarafı, bu görsellerde mazlum durumuna düşmektedir.

\section{Sonuç ve Sonuca Dair Tartışma Fikirleri}

Türkiye'deki Suriyelilere dair üretilen sosyal medya içeriklerine ilişkin analiz, Suriyelilerin Türkiye'deki korunma statüsünün meşruiyetinin çeşitli parametrelere bağlı olduğunun ve Suriyelilere ilişkin söylemin görsel kanıtlara başvurularak üretildiğini göstermiştir.

Sosyal medyada Suriyelilere ilişkin görsel paylaşımlarının duygusal bağlamlarla ifade edilmiş olmaları veya resmî bilgilere dayandırımamaları, bu etkileşimlerin posthakikat ekseninde konumlandırımasının nedenlerinden biridir. Bununla birlikte posthakikat anlayışının hâkim olduğu günümüzde, hakikate ilişkin iddialar, objektif olduğu düşünülen görüntülerden beslenmektedir. Sosyal medya platformlarında meydana gelen Türkiye'deki Suriyelilere ilişkin tartışmalarda, görüntüleri paylaşan kullanıcıların objektiflik ve tarafsızlık kaygısı taşıdıkları görülmektedir. Türkiye'deki Suriyelilere ilişkin görüntülerin çevrimiçi tartışmalarda gerçeklik kanıtı olarak kullanıldığı ve bu nedenle de objektiflik 
esasına dayalı olduğu ileri sürülen tanıklığa bağlandığı anlaşılmaktadır. Bunun yanında, fikir beyanını ve iddiaları güçlendirmek için paylaşıma eklenen görsellerde kolaj ile karşılaştırma yapılmaktadır. Bu görsellerde çeşitli renk ve kontrast efektlerinin veya çoklu katmanların üst üste konulmasıyla estetize edilmiş veya kurgulanmış mazlum Türk ve mazlum veya suiistimalci Suriyeli veya Türk erkeği ile Suriyeli erkek görselleri, farklııkları vurgulamak amacıyla paylaşımlarda yan yana durmaktadır. Burada amaç, görselde objektiflik göstergesi sunmak değil, görselin içinde savunulan iddianın temsiline yer vermektir. Ancak paylaşanın karşılaştırmasının sonucu olarak "mazlum" veya "çalışkan", "vatanî görev bilinci" taşıyan, "ahlaklı" olan tarafta dramatize estetik öğeler ön plana çıkarken bu özelliklere sahip olmayan taraf daha ham ve bu nedenle de natürel görünüm taşımaktadır. Dolayısıyla, kullanıcı görüntü seçerken veya kurgularken metinsel argümanının görsel formda da işlenmiş kurgu olarak yenilenmesini ve pekiştirilmesini tercih etmektedir. Buna ek olarak, Suriyeli göçmenlere dair görsellerdeki Oryantalist üslup; kendini Suriyeli imgesi ile harabe, düzensizlik, kontrolsüzlük, çatışma ve şiddet referanslarının bağdaşık olarak kurulmasıyla göstermektedir. Burada modern Batı karşısında geleneksel Doğu'nun inşasına benzer şekilde, Türkler ile Türkiye'de yaşayan Suriyeliler arasında hiyerarşik bir karşıtık kurulmaktadır. Bu nedenle, aslında Türkiye'deki Suriyeliler ile kültürel ve geleneksel farklılıkların çokluğu söylemi; ortak olabilecek din, etnisite, tarih ve coğrafyanın önüne geçmektedir. Ayrıca modern özel alan ve kamusal alan ayrımına dair tasvirlerde Suriyelilerin bu ayrıma uymadığı durumların sosyal medyada yer bulmasıyla Türkler ve Suriyeliler arasındaki farklılık iddiası pekiştirilmektedir.

$\mathrm{Bu}$ bağlamda araştırma sonucuna dair tartışabilecek öncelikli konu, toplumun görsellik ve hakikat üretimi arasındaki ilişkiselliği tanımanın sosyal entegrasyon için nasıl kullanılabileceğidir. Toplumun da paydaş sayılabilmesi için bu içeriklerin tema ve sorunsallarının, göstergebilimsel iletişim modelleri ve üslupları dikkate alınarak sosyal entegrasyon çalışmalarında incelenmesi tavsiye edilebilir. Cahil Hoca (Ignorant Schoolmaster, 1991) adlı çalışmasında Jacques Rancière, toplumun pedagojik tanımı alanında bazı kişi ve sınıfların jenerik olarak çocuklaştırılması sorununu ele almış ve bilgi 
otoritelerinin eğitimi meşrulaştırmak için bu "çocuksu" kesimlerin bilgi üretimindeki beceriksizliklerini eşitsizlik olarak tanımlayıp ürettiğini belirtmiştir (1991:133). Bilgi üretimi ve dağılımındaki kutuplaşma, tartışma eksenindeki herkesin ve öncelikle tartışmaya getirdiklerinin eşit varsayılmasıyla ortak düzlemde paylaşılabilir. Böylelikle, hakikat sonrası alanda eski bilgi otoritelerinin elitist, yani bilgi üretimi düzleminde taraflı ve hiyerarşik olarak kurulduğu kamusal alan ortaklaştırılabilir. Buradaki çevrimiçi kamusal alan ile görsel dil ve bilgi üretim uygulamaları, kendi rasyonellikleri içerisinde ötekileştirilmeden anlaşıımalı ve buna dair çözümler tartışılmalıdır. 


\section{Kaynakça}

Abid, Raith Zeher, vd. (2017). "'A flood of Syrians has slowed to a trickle': The use of metaphors in the representation of Syrian refugees in the online media news reports of host and non-host countries." Discourse \& Communication, 11(2), 121140. https://doi.org/10.1177/1750481317691857

Ahmed, Sara (2000). Strange Encounters: Embodied Others in Post-Coloniality. Abingdon: Routledge.

Aiello, Giorgia ve Crispin Thurlow (2006). "Symbolic Capitals: Visual Discourse and Intercultural Exchange in the European Capital of Culture Scheme." Language and Intercultural Communication, 6(2): 148-162. https://doi.org/10.2167/laic234.0

Arendt, Hannah (2006). On Revolution. Londra: Penguin Classics.

Atasü-Topçuoğlu, Reyhan (2019). "Media Discussion on the Naturalization Policy for Syrians in Turkey." International Migration, 57(2): 1-15. https://doi.org/10.1111/imig.12463

Baudrillard, Jean (1994). Simulacra and Simulation. Çev., Sheila Faria Glaser. Ann Arbor: The University of Michigan Press.

Birleşmiş Milletler Mülteciler Yüksek Komiserliği. What is a refugee? UNHCR. https://www.unhcr.org/what-is-a-refugee.html. Erişim tarihi: 11 Temmuz 2020.

Boltanski, Luc (1999). Distant Suffering: Morality, Media and Politics. Ingiltere: Cambridge University Press.

Bozdağ, Çiğdem ve Kevin Smetz (2017). "Understanding the Images of Alan Kurdi With 'Small Data': A Qualitative, Comparative Analysis of Tweets About Refugees in Turkey and Flanders." International Journal of Communication, 24: 4046-4069.

Bruns, Axel ve Folker Hanusch (2017). "Conflict imagery in a connective environment: Audiovisual content on Twitter following the 2015/2016 terror attacks in Paris and Brussels." Media, Culture \& Society, 39(8): 1122-1141. 
https://doi.org/10.1177/0163443717725574

Çelik, Hilal ve Halil Ekşi (2008). "Söylem Analizi." Marmara Üniversitesi Eğitim Bilimleri Dergisi, 27: 99-117.

de Guevara, Berit B. ve Roland Kostić (2017). "Knowledge production in/about conflict and intervention: Finding 'facts', telling 'truth'." Journal of Intervention and Statebuilding, 11(1): 1-20. https://doi.org/10.1080/17502977.2017.1287635

Deutsche Welle (2019) "Sosyal medyada 'Suriyelileri istemiyoruz' tartışması." 1 Ocak 2019. DW.COM. https://www.dw.com/tr/sosyal-medyada-suriyelileri-istemiyoruztart\%C4\%B1\%C5\%9Fmas\%C4\%B1/a-46917127. Erişim tarihi: 15.12.2020

Eco, Umberto (1995). Faith in Fakes: Travels in Hyperreality. Vintage UK.

Efe, İbrahim, vd. (2017) Türk Basınında Suriyeli Sığınmacı Temsillerinin Eleştirel Söylem Analizi (No. 115K268; Program Kodu 1001). Tübitak. İnternet sitesi: https://trdizin.gov.tr/publication/project/detail/TVRjME9EVTE=. Erişim tarihi: 05.08.2019

Erdoğan, Murat (2017). Suriyeliler Barometresi. İstanbul: İstanbul Bilgi Üniversitesi Yayınları.

Fahy, Declan (2018). "Objectivity as Trained Judgment: How Environmental Reporters Pioneered Journalism for a "Post-truth" Era." Environmental Communication, 12(7): 1-8. https://doi.org/10.1080/17524032.2018.1495093

Foucault, Michel (2001). Power. Çev., J. D. Faubion. New York: The New Press. Hand, Martin (2012). Ubiquitous Photography. Cambridge: Polity. Harsin, Jayson (2015). "Regimes of Posttruth, Postpolitics, and Attention Economies." Communication, Culture \& Critique, 8(2): 327-333. https://doi.org/10.1111/cccr.12097

Highfield, Tim ve Tama Leaver (2016). "Instagrammatics and digital methods: Studying visual social media, from selfies and GIFs to memes and emoji." Communication Research and Practice, 2(1): 47-62. 
https://doi.org/10.1080/22041451.2016.1155332

Hyland, Ken ve Brian Paltridge (2013). The Bloomsbury Companion to Discourse Analysis. Londra: Bloomsbury Academic.

Jenkins, Henry (2006). Convergence Culture: Where Old and New Media Collide. New York ve Londra: NYU Press.

Johnson, Heather L. (2011). "Click to Donate: Visual images, constructing victims and imagining the female refugee." Third World Quarterly, 32(6): 1015-1037. https://doi.org/10.1080/01436597.2011.586235

Jowett, Garth S. ve Victoria J. O'Donnell (2011). Propaganda \& Persuasion. New York: Sage Publications.

Kenney, Keith (2010). Visual Communication Research Designs. İngiltere: Routledge.

Kozinets, Robert V. (2010). Netnography: Doing Ethnographic Research Online. Londra: Sage Publications.

Kress, Gunther R. ve Theo van Leeuwen (2001). Multimodal Discourse: The Modes and Media of Contemporary Communication. Londra: Bloomsbury Academic.

Lackovic, Nataša (2020). "Thinking with digital images in the post-truth era:a method in critical media literacy." Postdigital Science and Education, 2: 442-462.

Lewandowsky, Stephan, vd. (2017). "Beyond Misinformation: Understanding and Coping with the 'Post-Truth' Era." Journal of Applied Research in Memory and Cognition, 6(4): 353-369. https://doi.org/10.1016/j.jarmac.2017.07.008

McNaughton, Melanie Joy (2013). "Reimagining What Images Can Achieve." Journal of Mass Media Ethics, 28(2): 140-142.

Mitchell, William J. T. (1984). "What is an image?" New Literary History, 15(3): 503-537.

Mortensen, Mette (2015). "Conflictual Media Events, Eyewitness Images, and the Boston Marathon Bombing." Journalism Practice, 9(4): 536-551. https://doi.org/10.1080/17512786.2015.1030140

Özdemir, Fatih ve Bengi Öner-Özkan (2016). "Türkiye'de Sosyal Medya Kullanıcılarının 
Suriyeli Mültecilere İlişkin Sosyal Temsilleri." Nesne Psikoloji Dergisi, 4(8): 227244. https://doi.org/10.7816/nesne-04-08-04

Papacharissi, Zizi. (2014). Affective Publics: Sentiment, Technology, and Politics. Oxford: Oxford University Press.

Papacharissi, Zizi (2010). A Private Sphere: Democracy in a Digital Age. Cambridge: Polity.

Papakostas, Apostolis (2016). Civilizing the Public Sphere: Distrust, Trust and Corruption. Basingstoke: Palgrave Macmillan.

Peters, Michael A. (2017). "Education in a post-truth world". Educational Philosophy and Theory, 49(6): 563-566. https://doi.org/10.1080/00131857.2016.1264114

Rajaram, Prem Kumar (2002). "Humanitarianism and Representations of the Refugee." Journal of Refugee Studies, 15(3): 247-264.

Rancière, Jacques (1991). The Ignorant Schoolmaster: Five Lessons in Intellectual Emancipation. Stanford, CA: Stanford University Press.

Renshaw, Scott W. (2002). "Postmodern Swing Dance and the Presentation of Unique Self." Postmodern Existential Sociology. J. A. Kotarba ve J. M. Johnson (der.) içinde. Walnut Creek, CA: AltaMira. 83-94.

Said, Edward (2003). Orientalism. Londra: Penguin Books, Limited.

Scott, Sasha (2019). "Mediatized Witnessing and the Ethical Imperative of Capture." Media Controversy: Breakthroughs in Research and Practice: Breakthroughs in Research and Practice. M. Khosrow-Pour (ed.) içinde. Pennsylvania: IGI Global. 373-386.

Seo, Hyunjin ve Husain Ebrahim (2016). "Visual propaganda on Facebook: A comparative analysis of Syrian conflicts." Media, War \& Conflict, 9(3): 227-251. https://doi.org/10.1177/1750635216661648

Taş, Oğuzhan ve Tuğba Taş (2018). "Post-Hakikat Çağında Sosyal Medyada Yalan Haber ve Suriyeli Mülteciler Sorunu." Galatasaray Üniversitesi Ileti-ş-im Dergisi: 
183-208. https://doi.org/10.16878/gsuilet.500943

Şuşar, Sara Vildan (2019). "Fotoğrafın Denizde Nargile İçen Bir Suriyeliyi Gösterdiği İddiası." https://teyit.org/fotografin-denizde-nargile-icen-bir-suriyeliyi-gosterdigiiddiasi. Erişim Tarihi: 01.01.2020

UN Refugee Agency. (2020). Situation Syria Regional Refugee Response. Operational Data Portal by UNHCR. https://data2.unhcr.org/en/situations/syria/location/113. Erişim tarihi: 26.12.2020

Walther, Joseph B. (2002). "Research Ethics in Internet-Enabled Research: Human Subjects Issues and Methodological Myopia." Ethics and Information Technology, 4: 205-216.

Young, Alison (2010). "The scene of the crime: Is there such a thing as 'just looking'?" Framing Crime: Cultural Criminology and the Image. K. Hayward (der.) içinde. Abingdon: Routledge. 83-97. 